\title{
Hypovitaminosis D in Obese and Overweight Schoolchildren
}

\author{
Filiz Mine Çizmecioğlu${ }^{1}$, Nilay Etiler ${ }^{2}$, Uzay Görmüş ${ }^{3}$, Onur Hamzaoğlu², Şükrü Hatun ${ }^{1}$ \\ ${ }^{1}$ Division of Endocrinology and Diabetes, Department of Pediatrics, Kocaeli University, Faculty of Medicine, Kocaeli, Turkey \\ ${ }^{2}$ Department of Public Health, Kocaeli University, Faculty of Medicine, Kocaeli, Turkey \\ ${ }^{3}$ Department of Molecular Medicine, Istanbul University, Istanbul, Turkey
}

\section{Keywords: \\ Vitamin D, hypovitaminosis D, schoolchildren, obesity, adolescents \\ Received: 25 November, 2008 Accepted: 15 December, 2008 \\ Corresponding Author: Filiz Mine Çizmecioğlu Division of Endocrinology and Diabetes, Department of Pediatrics, Kocaeli University, Faculty of Medicine Kocaeli, Turkey. 41380 \\ Tel: +90-262-303 7228 Fax: +90-262-303 8003 E-mail: filizcizmeci@gmail.com}

\section{ABSTRACT}

Aim: To determine the prevalence of vitamin D hypovitaminosis among obese and overweight schoolchildren.

Design: A cross-sectional population based sample.

Methods: In a cross-sectional study, 301 students (177 girls and 124 boys) aged 11-19 years were selected by multistage stratified sampling design. Subjects were classified according to their body mass index as obese, overweight and normal. Serum 25-hydroxyvitamin D (25-OHD), intact parathyroid hormone (iPTH) and alkaline phosphatase (ALP) were measured in late winter months. Vitamin D deficiency was defined as a $25-\mathrm{OHD}<10 \mathrm{ng} / \mathrm{ml}$, insufficiency as $25-\mathrm{OHD} 10$ to $20 \mathrm{ng} / \mathrm{ml}$, and normal vitamin D level as $>20 \mathrm{ng} / \mathrm{ml}$.

Results: The prevalence of hypovitaminosis D was found as $65 \%$ in all students. Vitamin D deficiency was found in $12 \%$ and insufficiency in $53 \%$ of all students. Vitamin D deficiency in female students was about two times more common than in males. In obese and overweight schoolchildren with hypovitaminosis $\mathrm{D}$, serum 25-OHD levels decreased as BMI increased. There were no correlations between serum 25-OHD and ALP and iPTH levels.

Conclusion: Vitamin D deficiency and insufficiency are common in obese and overweight schoolchildren, especially in girls. Obesity could be a risk factor in terms of hypovitaminosis $D$ in adolescents. Vitamin D supplementation should be administered particularly to adolescent girls.

Conflict of interest: None declared

\section{INTRODUCTION}

Recently clinical and subclinical vita-

\section{ORIGINAL} ARTICLE min D deficiency has, once again, become a current issue. High rates of subclinical vitamin $\mathrm{D}$ deficiency have been reported among some risk groups such as immigrants in Europe from the Middle East and Asia, African Americans and adolescents from various countries. (1, 2, 3, 4, 5 ,6) Vitamin D insufficiency among healthy adolescents was reported as $78 \%$ in 
France, 65\% in Finland, 52\% in Beirut, 42.5\% in Beijing, 42\% in Boston, 47\% in Greece, $46.2 \%$ in Iran and 29\% in Switzerland. (7, 8, 9, 10, 11, 12, 13, 14, 15, 16) Similarly in Turkey, hypovitaminosis D rate is $59.4 \%$ among adolescents in Izmir, which is a sunny seaside city.(17) Previously we had reported high rates of subclinical vitamin $\mathrm{D}$ deficiency (65\%) in adolescent girls who wear concealing clothing in the Kocaeli region.(18)

Inadequate vitamin $\mathrm{D}$ intake has been associated with obesity in young adults.(19) Recent limited studies have pointed out a relation between obesity and vitamin $\mathrm{D}$ hypovitaminosis which are frequent in adolescence because of changing life styles.(20)

In this study we aimed to determine the prevalence of vitamin D hypovitaminosis in both sexes among schoolchildren, many of whom were obese and overweight in our highly industrialized city.

\section{METHOD}

\section{Subjects}

This cross-sectional study was performed in Kocaeli, a highly industrialized region located in northwestern Turkey at a latitude of $30^{\circ} \mathrm{E}$ and $40^{\circ} \mathrm{N}$ in the late winter months. Participants for this study were recruited from the study samples which consisted of secondary and highschoolchildren, aged 11-18 years, using a multistage, stratified sampling design for the epidemiological study to determine metabolic syndrome prevalence. A total of 301 schoolchildren from 3 different towns (İzmit, Gebze and Kandira) were included in the study. The first two of these towns are highly industrialized areas and third is a non-industrialized seaside town. For sample selection, the schools were stratified and weighted first as urban vs rural area and next as state owned vs private school. After obtaining each stratum's weights, the schools and the students were selected using random numbers from the students' list. At the first stage of the study, anthropometric measurements of 2491 subjects participating in the research were performed in the schools after obtaining verbal informed consent from the children. At the second stage, participants whose body mass index (BMI, calculated as $\mathrm{kg} / \mathrm{m}^{2}$ ) was $\geq 85^{\text {th }}$ centile were invited to the hospital for further investigation. CDC reference values were used for assessment of overweight and obesity.(21) Of these 301 children and adolescents who were included in the study, 102 were obese (34\%), 145 were overweight (48\%). BMI values were within normal percentile ranges in 54 (18\%) who had lost weight and returned to normal BMI when the blood samples were collected for further investigation. BMI standard deviation score (SDS) and centiles were obtained according to CDC reference value.(21)

Subjects were evaluated according to pubertal stages. Tanner stage I was defined as pre-puberty, Tanner stage II-IV as midpuberty and Tanner stage $\mathrm{V}$ as post-puberty.

Children with any systemic disease or using any medications or supplements known to affect skeletal metabolism were excluded from the study. Written informed consent was also obtained from all parents and subjects at the second stage of the study. This study was approved by the Ethics Committee of Kocaeli University. Permission for the study was granted by the Directorate of National Education of Kocaeli.

\section{Laboratory tests}

After an overnight fast morning blood samples were taken from the participants for serum 25-hydroxyvitamin D (25-OHD), intact parathyroid hormone (iPTH) and alkaline phosphatase (ALP) measurements. Vitamin D deficiency was defined as a 25OHD blood level of $<10 \mathrm{ng} / \mathrm{ml}$, vitamin $\mathrm{D}$ insufficiency as levels of 25-OHD between 10 and $20 \mathrm{ng} / \mathrm{ml}$, and a normal vitamin D level as $>20 \mathrm{ng} / \mathrm{ml} .(22,23)$ The subjects were divided into 3 categories (vitamin D 
Table 1: Anthropometric characteristics of the subjects by sex

\begin{tabular}{|c|c|c|c|c|c|}
\hline Characteristics & \multicolumn{2}{|c|}{ Boys $(n=124)$} & \multicolumn{2}{|c|}{ Girls $(n=177)$} & $\mathrm{p}$ \\
\hline Age (years) & $14.0 \pm 2.0$ & $11.1-18.7$ & $14.3 \pm 1.7$ & $11-18.6$ & NS \\
\hline Height (cm) & $160.8 \pm 11.4$ & $130.3-190.3$ & $156.3 \pm 5.8$ & $141.0-172.0$ & $<0.05$ \\
\hline Weight (kg) & $65.1 \pm 15.5$ & 41.0-114.1 & $65.1 \pm 11.4$ & $43.4-106.4$ & NS \\
\hline BMI $\left(\mathrm{kg} / \mathrm{m}^{2}\right)$ & $25.2 \pm 3.7$ & $19.9-37.7$ & $26.5 \pm 3.8$ & $19.3-40.3$ & $<0.05$ \\
\hline BMI SDS & $1.44 \pm 0.47$ & $0.44-2.59$ & $1.45 \pm 0.41$ & $0.34-1.72$ & NS \\
\hline
\end{tabular}

\section{Table 2: Vitamin D status of subjects by sex}

\begin{tabular}{|c|c|c|c|c|}
\hline 25-OH D (ng/ml) & Boys n (\%) & Girls n (\%) & Total n (\%) & $\mathrm{p}^{*}$ \\
\hline Group A (<10 ng/ml) & $8(6.5)$ & $27(15.3)$ & $35(11.6)$ & \multirow{3}{*}{0.001} \\
\hline Group B (10-20 ng/ml) & $59(47.6)$ & $102(57.6)$ & $161(53.5)$ & \\
\hline Group C (>20 ng/ml) & $57(46.0)$ & $48(27.1)$ & $105(34.9)$ & \\
\hline Total & $124(41.0)$ & $177(59.0)$ & $301(100)$ & \\
\hline
\end{tabular}

deficiency, group A; vitamin D insufficiency, group B; normal or vitamin D competent, group C), according to their serum 25-OHD concentrations.

A competitive protein binding assay was used to measure 25-OH Vit D levels (Vita D EIA kit, Immundiagnostic, Bensheim, Germany). The normal range for 25-OHD was stated as 11 to $70 \mathrm{ng} / \mathrm{mL}$ and intra-and interassay coefficients of variation (CVs) were $10.7 \%$ and $13.2 \%$ respectively. Serum iPTH was measured by using chemiluminescence with an Immulite One analyzer. The reference range suggested by this method is $12-65 \mathrm{pg} / \mathrm{ml}$, and total coefficients of variation are $2.8 \%$, and $3.4 \%$ respectively. Serum levels of ALP were measured using original assays by Aeroset autoanalyser equipment.

\section{Statistical analysis}

The data were analyzed with Statistical Package for the Social Sciences (SPSS Inc., Chicago) Version 11.5. Two sample independent group t-test was performed to compare some characteristics and 25-OHD categories between boys and girls. The chi-square test was used to assess fre- quency differences between 25-OHD categories. The relationships between 25OHD and some variables (BMI, ALP, PTH) were evaluated using a Pearson correlation coefficient. Significance was accepted at a $\mathrm{p}<0.05$.

\section{RESULTS}

\section{Characteristics of the study groups}

A total of 301 schoolchildren and adolescents were studied. The mean age (range) of the students was $14.2 \pm 1.8(11.0-18.7)$. 59\% were female $(n=177)$ and $41 \%(n=124)$ male, $67 \%$ were $(n=201)$ post-pubertal, 29\% $(n=88)$ were mid-pubertal (Tanner stage between IIIV) and 4\% were $(n=12)$ pre-pubertal. Fifty nine percent of the children $(n=177)$ were secondary school students and 41\% $(n=124)$ were in highschool. Their anthropometric characteristics are shown in Table 1.

\section{Prevalence of hypovitaminosis D}

Serum levels of 25-OHD in the total group ranged between 2.8 and $72 \mathrm{ng} / \mathrm{ml}$. The mean level of 25-OHD was significantly lower in girls compared to boys (M;

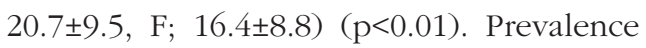




\section{Table 3: Vitamin D status by obesity status}

\begin{tabular}{|c|c|c|c|c|c|}
\hline \multirow[b]{2}{*}{ BMI $\left(\mathrm{kg} / \mathrm{m}^{2}\right)$} & \multicolumn{4}{|c|}{$25-\mathrm{OH}$ D vitamin $(\mathrm{ng} / \mathrm{ml})$} & \multirow[b]{2}{*}{$\mathrm{p}$} \\
\hline & Grup A n (\%) & Grup B n (\%) & Grup C n (\%) & Total n (\%) & \\
\hline$<85^{\text {th }}$ centile & $4(7.4)$ & $34(63.0)$ & $16(29.6)$ & $54(100.0)$ & \multirow{3}{*}{ NS } \\
\hline $85-95^{\text {th }}$ centile & $18(12.4)$ & $76(52.4)$ & $51(35.2)$ & $145(100.0)$ & \\
\hline$>95^{\text {th }}$ centile & $13(12.7)$ & $51(50.0)$ & $38(37.3)$ & $102(100.0)$ & \\
\hline
\end{tabular}

Table 4: Vitamin D status according by place of residence

\begin{tabular}{|l|l|l|l|l|l|}
\hline Town & n & Group A & Group B & Group C & p * \\
\hline Izmit & 141 & 20 & 71 & 50 & $<0.05$ \\
\hline Gebze & 147 & 15 & 86 & 46 & 7 \\
\hline Kandıra & 9 & 0 & 2 & 103 & \\
\hline Total & 297 & 297 & 159 & & \\
\hline * Difference caused by Kandıra. & & & & \\
\hline
\end{tabular}

of vitamin D deficiency was $12 \%$ and insufficiency was $53 \%$ in the total group. The proportion of children with vitamin D levels below normal was 65\%. There were significant differences in vitamin D levels between the two sexes $(\mathrm{p}<0.001)$. Prevalence of vitamin D deficiency in female students, a seen in Table 2, was about two times more common than in males.

Vitamin D status was assessed according to its relationship to obesity and also to place of residence.

Vitamin D levels and obesity: Mean BMI of the total group was $26.0 \pm 3.8 \mathrm{ng} / \mathrm{ml}(19.3$ - 40.3) and mean (range) of BMI SDS was 1.5 \pm 0.4 (range 0.3-2.6). Although the girls appeared to have higher BMI values than the boys, there was no statistically significant difference between their BMI SDS values. There was also no relation between obesity status and vitamin D categories (Table 3). However, we found a negative correlation between serum vitamin D level and BMI in obese and overweight subjects whose vitamin D level was below $20 \mathrm{ng} / \mathrm{ml}$ (r: - $0.186 \mathrm{p}<0.01)$ (Figure 1).

Vitamin D levels and place of residence: While mean vitamin D level in Kandira was $22.2 \pm 5 \mathrm{ng} / \mathrm{ml}$ (12.4-27.4), it was 19.0 \pm 11.7 (2.8-11.7) in İzmit and $17.1 \pm 6.6 \mathrm{ng} / \mathrm{ml}$ (5.7$40)$ in Gebze $(p=0.078)$. The prevalence of vitamin D deficiency and insufficiency were low in Kandira $(\mathrm{p}<0.05)$ (Table 4$)$.

There were no relationships between serum 25 OHD and iPTH or ALP levels (r:0.074, $\mathrm{p}=0.202$, r: 0.078, $\mathrm{p}=0.175$, respectively).

\section{DISCUSSION}

In consistency with previous reports, vitamin D deficiency among adolescents in our country is a common problem. ${ }^{17,18}$ When we use the recently proposed cut-off values for optimal vitamin D level (normal >20 $\mathrm{ng} / \mathrm{ml}$, vitamin D deficiency $<10 \mathrm{ng} / \mathrm{ml}$ and 20-30 ng/ml, vitamin D insufficiency),(24, 26 ) only $6 \%$ of subjects had normal vitamin D concentrations, 29\% were vitamin D insufficient and $65 \%$ were vitamin D deficient. The main importance of this issue is whether this condition will have any clinical impact on human health at long term. While studies in western countries reported no difference between sexes regarding prevalence of hypovitaminosis $\mathrm{D}$, studies in the Middle East demonstrated a significant deficiency in the girls, as in our study. $(8,9$, $16,18)$ This might be due to differences in life styles but has not been investigated. While all of the schoolgirls in the study of Moussavi et al(15) were veiled, none were veiled in our study. Although we live in a 
Figure 1: The correlation between serum 25-OHD level and BMI in obese and overweight subjects with vitamin D levels $<20 \mathrm{ng} / \mathrm{ml}$. The 25-OHD levels correlated negatively with BMI (r: - 0.186, p<0.01).

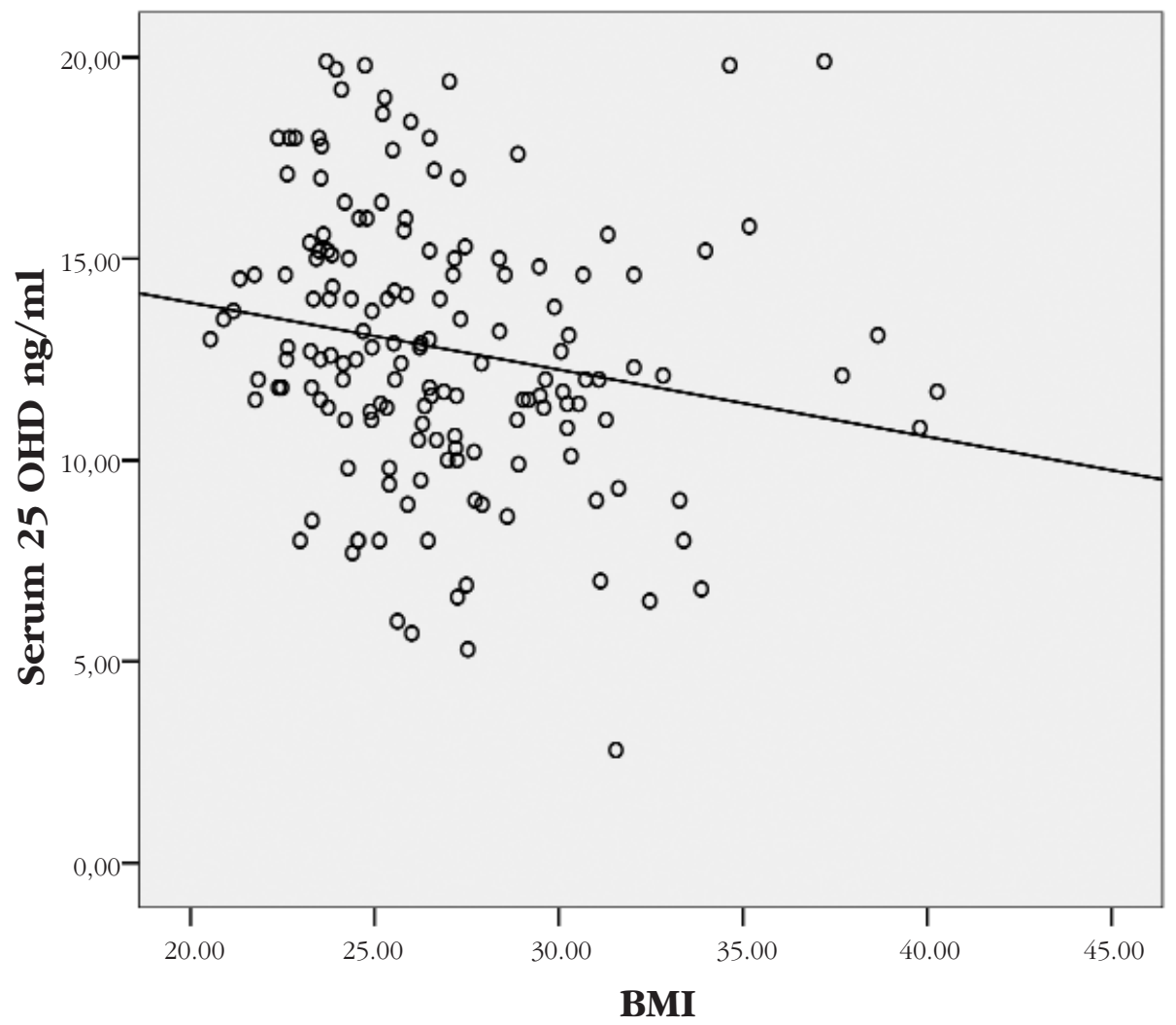

sunny country, high rates of hypovitaminosis D might be associated with air-pollution in highly industrialized regions. In our study while the rate of vitamin D deficiency was high in industrialized towns, it was much lower in Kandira, a rural seaside town. Although sample size was limited in Kandıra, the absence of vitamin D deficiency and the high mean serum vitamin D levels suggest the role of UV radiation.

There are two main biochemical parameters regarding the negative effects of vitamin $\mathrm{D}$ deficiency on the skeleton namely ALP and iPTH. The cut-off point of serum 25OHD in which the mean serum PTH concentration begins to increase is defined as 20 or $30 \mathrm{ng} / \mathrm{ml} .(9,13,15,22,27,28,29)$ When we used a cut-off point of $20 \mathrm{ng} / \mathrm{ml}$ and even a cut-off level $10 \mathrm{ng} / \mathrm{ml}$, we were not able to demonstrate secondary hyperparathyroidism, nor a correlation between serum 25-OHD and ALP and iPTH levels. This might be due to the cross-sectional design of the study. We do not know how long these children have been suffering from hypovitaminosis D. For this reason, ALP and PTH concentrations of subjects with hypovitaminosis D should be followed at long term. Another important issue is the treatment approach in subjects with vitamin D deficiency whose ALP and PTH levels are not elevated. Whether pharmacological doses of vitamin D or physiological doses should be administered is not clear.

There are many reasons for the high frequency of vitamin D deficiency which differ according to countries. In our previous study, the most important reason was concealing 
clothing.(18) In this study we assessed the impact of obesity. In the literature, some reports showed no interaction of BMI and vitamin D, but particularly studies on adults and a few on children demonstrated a relation between obesity and vitamin D deficiency.(9, 14, 19, 20, 30, 31) We did not observe any relation between obesity status and vitamin D categories. However, in obese and overweight schoolchildren with hypovitaminosis $\mathrm{D}$, serum 25-OHD levels decreased as BMI increased. This inverse relationship is in consistency with the hypothesis suggesting that the increased adipose tissue decreases vitamin D bioavailability by sequestration in body fat. $(19,31)$ However, whether obese children and adolescents require a separate dose of vitamin D supplementation is controversial.(31)

Although the clinical importance of rickets is well known, the effects of subclinical vitamin $\mathrm{D}$ deficiency on human health are still under debate. Vitamin D receptor (VDR) is present in the small intestine, bone and in the kidney, which all have major responsibilities for regulating calcium and phosphorous metabolism. It is reported that the skin, brain, gonads, colon, beta-islet cells, prostate, heart, skeletal muscle, monocytes, activated $\mathrm{T}$ and $\mathrm{B}$ lymphocytes and adipocytes all express the same VDR.(31, 32) Recent studies on VDR in knockout mice revealed that the effects of vitamin $\mathrm{D}$ on skeletal health depend exclusively on intestinal Ca absorption.(33) Therefore, the assumption that in various tissues the effect of vitamin D deficiency below the level affecting $\mathrm{Ca}$ homeostasis is mediated through VDR, is controversial. However, in many epidemiological studies hypovitaminosis D is associated with chronic diseases and malignancy. $(34,35,36)$

Subclinical vitamin D deficiency not only affects bone health but also has other more serious non-skeletal consequences such as diabetes, hypertension and malignancy. Therefore, in order to prevent the potential chronic diseases in the future, vitamin D supplementation should be administered throughout childhood to both genders, particularly to adolescent girls. Cross-sectional design and also the limited number of students from the non-industrialized region was the limitation of this study. Further longitudinal studies are necessary to define the dose and duration of vitamin D supplementation in childhood considering the confounding factors that might cause hypovitaminosis D.

\section{ACKNOWLEDGEMENTS}

We would like to thank Prof. Dr. Nezih Hekimi, Dr. Dilek Erdonmez, Dr. Cavit Işık Yavuz due to contributions about statistical analysis, data collection and vitamin D assay, and we are grateful to intern doctors, nurses and staff who worked during the $1^{\text {st }}$ and $2^{\text {nd }}$ steps of the study. Finally, we express our gratitude to the children and their families for making this study possible.

\section{REFERENCES}

1. Lips P. Vitamin D status and nutrition in Europe and Asia. J Steroid Biochem Mol Biol 2007;103:620625. [Abstract / PDF]

2. Looker AC, Dawson-Hughes B, Calvo MS, Gunter EW, Sahyoun NR. Serum 25-hydroxyvitamin D status of adolescents and adults in two seasonal subpopulations from NHANES III. Bone 2002;30:771777. [Abstract]

3. Sullivan SS, Rosen CJ, Halteman WA, Chen TC, Holick MF. Adolescent girls in Maine are at risk for vitamin D insufficiency. J Am Diet Assoc 2005;105:971-974. [Abstract / Full Text / PDF]

4. Tangpricha $V$, Pearce EN, Chen TC, Holick MF. Vitamin D insufficiency among free-living healthy young adults. Am J Med 2002;112:659-662. [Abstract]

5. Hill TR, Flynn A, Kiely M, Cashman KD. Prevalence of suboptimal vitamin D status in young, adult and elderly Irish subjects. Ir Med J 2006;99:48-49. [Abstract] 
6. Das G, Crocombe S, McGrath M, Berry JL, Mughal MZ. Hypovitaminosis D among healthy adolescent girls attending an inner city school. Arch Dis Child 2006;91:569-572. [Abstract / PDF]

7. Scharla SH. Prevalence of subclinical vitamin D deficiency in different European countries. Osteoporos Int 1998;8:7-12. [Abstract / PDF]

8. El-Hajj Fuleihan G, Nabulsi M, Choucair M, Salamoun M, Hajj Shahine C, Kizirian A, Tannous R. Hypovitaminosis D in healthy school children. Pediatrics 2001;107:e53;1-7. [Abstract]

9. Gordon CM, DePeter KC, Feldman HA, Grace E, Emans SJ. Prevalence of vitamin D deficiency among healthy adolescents. Arch Pediatr Adolesc Med 2004;158:531-537. [Abstract / Full Text / PDF]

10. Lehtonen-Veromaa M, Möttönen T, Irjala K, Kärkkäinen M, Lamberg-Allardt C, Hakola P, Viikari J. Vitamin $D$ intake is low and hypovitaminosis D common in healthy 9- to 15-year-old Finnish girls. Eur J Clin Nutr 1999;53: 746-751. [Abstract / Full Text / PDF]

11. Ginty F, Cavadini C, Michaud PA, Burckhardt P, Baumgartner M, Mishra GD, Barclay DV. Effects of usual nutrient intake and vitamin D status on markers of bone turnover in Swiss adolescents. Eur J Clin Nutr 2004;58:1257-1265. [Abstract / Full Text / PDF]

12. Lapatsanis D, Moulas A, Cholevas V, Soukakos P, Papadopoulou ZL, Challa A. Vitamin D: a necessity for children and adolescents in Greece. Calcif Tissue Int 2005; 77:348-355. [Abstract / Full Text]

13. Guillemant J, Taupin P, Le HT, Taright N, Allemandou A, Pérès G, Guillemant S. Vitamin D status during puberty in French healthy male adolescents. Osteoporos Int 1999;10: 222-225. [Abstract / Full Text]

14. Du X, Greenfield H, Fraser DR, Ge K, Trube A, Wang Y. Vitamin D deficiency and associated factors in adolescent girls in Beijing. Am J Clin Nutr 2001;74:494-500. [Abstract / Full Text / PDF]

15. Moussavi M, Heidarpour R, Aminorroaya A, Pournaghshband Z, Amini M. Prevalence of vitamin D deficiency in Isfahani high school students in 2004. Horm Res 2005;64:144-148. [Abstract / Full Text / PDF]

16. Dahifar H, Faraji A, Yassobi S, Ghorbani A. Asymptomatic rickets in adolescent girls. Indian J Pediatr 2007;74:571-575. [Abstract / Full Text]

17. Olmez D, Bober E, Buyukgebiz A, Cimrin D. The frequency of vitamin D insufficiency in healthy female adolescents. Acta Paediatr 2006;95:1266-1269. [Abstract]

18. Hatun S, Islam O, Cizmecioglu F, Kara B, Babaoglu K, Berk F, Gökalp AS. Subclinical vitamin D deficiency is increased in adolescent girls who wear concealing clothing. J Nutr 2005;135:218-222. [Abstract / Full Text / PDF]

19. Bell NH, Epstein S, Greene A, Shary J, Oexmann MJ, Shaw S. Evidence for alteration of the vitamin D endocrine system in obese subjects. J Clin Invest 1985;76:370-373. [Abstract / PDF]

20. Smotkin-Tangorra M, Purushothaman R, Gupta A, Nejati G, Anhalt H, Ten S. Prevalence of vitamin D insufficiency in obese children and adolescents. J Pediatr Endocrinol Metab 2007;20:817-823. [Abstract]

21. CDC (Centers for Disease Control and Prevention) BMI for Children and Teens. National Health and Nutrition Examination Survey: www cdc.gov/growth charts.

22. McKenna MJ, Freaney R. Secondary hyperparathyroidism in the elderly: means to defining hypovitaminosis D. Osteoporos Int 1998;8:S3-S6. [Abstract]

23. American Academy of Pediatrics. Clinical Report: Prevention of Rickets and Vitamin D Deficiency: New Guidelines for Vitamin D. Pediatrics 2003;111:908-910. [Abstract / Full Text / PDF]

24. Grant WB, Holick MF. Benefits and requirements of vitamin D for optimal health: a review. Altern Med Rev 2005;10:94-111. [Abstract]

25. Bischoff-Ferrari HA. The 25-hydroxyvitamin D threshold for better health. J Steroid Biochem Mol Biol 2007;103:614-619. [Abstract / PDF]

26. Glowacki J. Vitamin D inadequacy in 2007: what it is and how to manage it. Curr Opin Orthop 2007;18:480-485. [Abstract / Full Text / PDF]

27. Cheng S, Tylavsky F, Kröger H, Kärkkäinen M, Lyytikäinen A, Koistinen A, Mahonen A, Alen M, Halleen J, Vaananen K, Lamberg-Allardt C. Association of low 25-hydroxyvitamin D concentrations with elevated parathyroid hormone concentrations and low cortical bone density in early pubertal and prepubertal Finnish girls. Am J Clin Nutr 2003;78:485-492. [Abstract / Full Text / PDF] 
28. Sahota O, Mundey MK, San P, Godber IM, Lawson N, Hosking DJ. The relationship between vitamin $D$ and parathyroid hormone: calcium homeostasis, bone turnover, and bone mineral density in postmenopausal women with established osteoporosis. Bone 2004;35:312-319. [Abstract]

29. Aloia JF, Talwar SA, Pollack S, Feuerman M, Yeh JK. Optimal vitamin D status and serum parathyroid hormone concentrations in African American women. Am J Clin Nutr 2006;84:602-609. [Abstract / Full Text / PDF]

30. Parikh SJ, Edelman M, Uwaifo Gl, Freedman RJ, Semega-Janneh M, Reynolds J, Yanovski JA. The relationship between obesity and serum 1,25-dihydroxy vitamin D concentrations in healthy adults. J Clin Endocrinol Metab 2004;89:1196-1199. [Abstract / Full Text / PDF]

31. Holick MF. Vitamin D deficiency in obesity and health consequences. Curr Opin Endo Diab Obes 2006;13:412-418. [Abstract / Full Text / PDF]

32. Holick MF. Vitamin D deficiency. N Engl J Med 2007;357:266-281. [Abstract / Full Text / PDF]

33. Demay MB, Sabbagh Y, Carpenter TO. Calcium and vitamin D: What is known about the effects on growing bone. Pediatrics 2007(Supl 2);119:S141-S144. [Abstract / Full Text / PDF]

34. Holick MF. Vitamin D: A millenium perspective. J Cell Biochem 2003;88:296-307. [Abstract]

35. Holick MF. High prevalence of vitamin D inadequacy and implications for health. Mayo Clin Proc 2006;81:353-373. [Abstract / PDF]

36. Bischoff-Ferrari HA, Giovannucci E, Willett WC, Dietrich T, Dawson-Hughes B. Estimation of optimal serum concentrations of 25-hydroxyvitamin D for multiple health outcomes. Am J Clin Nutr 2006;84:18-28. [Abstract / Full Text / PDF] 